\title{
EFEKTIVITAS PENGGUNAAN MEDIA YOUTUBE BERBASIS VARIOUS APPROACHES DALAM MENINGKATKAN MOTIVASI BELAJAR BAHASA INGGRIS
}

\author{
Yusri $^{1}$, Ana Rosida ${ }^{2}$, Jufri $^{3}$, dan Mantasiah $\mathbf{R}^{4}$ \\ ${ }^{1,2}$ Program Studi Sastra Inggris, Universitas Fajar, Makassar \\ ${ }^{3,4}$ Pendidikan Bahasa Asing, Universitas Negeri Makassar, Makassar \\ Email: yusriugm@gmail.com
}

Tujuan penelitian ini ialah untuk mengetahui efektivitas penggunaan media youtube berbasis various approaches dalam meningkatkan motivasi belajar pembelajar bahasa Inggris. Penelitian ini merupakan penelitian tindakan kelas. Teknik pengumpulan data yang digunakan dalam penelitian ini terdiri atas observasi dan angket. Subjek dalam penelitian ini ialah berjumlah 35 orang. Penelitian ini dilaksanakan dalam dua siklus, yang setiap siklusnya dilaksanakan dua kali pertemuan. Pada tes awal, rata-rata motivasi belajar sebesar 33,74, pada siklus pertama sebesar 41,25 dan pada siklus kedua sebesar 48,28. Maka dari itu, jika kita bandingkan dari tes awal sampai pada tes siklus kedua. Terdapat peningkatan sebesar 14,54. Hal ini menunjukkan bahwa penggunaan media youtube berpengaruh terhadap peningkatan motivasi belajar Bahasa Inggris siswa.

Kata Kunci: Various Approaches, Bahasa Inggris, Media Youtube dan Motivasi Belajar.

\begin{abstract}
The purpose of this study was to determine the effectiveness of using youtube media based on various approaches in improving the learning motivation of English learners. This research is a classroom action research. Data collection techniques used in this study consisted of observations and questionnaires. The subjects in this study were 35 people. This research was carried out in two cycles, each meeting held two meetings. In the initial test, the average learning motivation was 33.74, in the first cycle was 41.25 and in the second cycle was 48.28. Therefore, if we compare it from the initial test to the second cycle test. There is an increase of 14.54. This shows that the use of youtube media has an effect on increasing students' motivation to learn English.
\end{abstract}

Keywords: Various Approaches, English, Youtube Media and Learning Motivation.

\section{PENDAHULUAN}

Pembelajaran bahasa asing telah menjadi salah satu topik penting untuk dikaji. Terdapat beberapa penelitian sebelumnya yang telah mengkaji faktor-faktor yang dapat memengaruhi prestasi ataupun hasil belajar peserta didik dalam mempelajari bahasa asing, baik itu dari aspek model pembelajaran yang digunakan (Yusri et all, 2018; Mantasiah et all, 2018; Romadloni et all, 2017; Quddus et all, 2017; Qalbi et all, 2017), maupun dari aspek media pembelajaran yang digunakan
(Zheng et all, 2018; Aniroh et all, 2018; Volkova et all, 2018).

Terdapat berbagai permasalahan yang sering kita temukan dalam proses pembelajaran, baik permasalahan yang bersifat ekternal seperti sarana dan prasarana, model pembelajaran yang digunakan serta permasalahan lainnya. Selain permasalahan ekternal, terdapat juga permasalahan internal yang dalam hal ini merupakan masalah yang berasal dari dalam diri siswa sebagai peserta didik. Salah satu contoh permasalahan 
internal dalam hal ini yakni motivasi belajar siswa. Dari hasil observasi yang telah dilakukan oleh peneliti dalam proses pembelajaran bahasa Inggris di salah satu sekolah menengah atas di Kota Makassar, diperoleh bahwa terdapat beberapa permasalahan selama proses pembelajaran bahasa Inggris. Salah satu permasalahan dijumpai dalam kelas ini yaitu kurangya motivasi belajar siswa. Hal tersebut dapat dilihat dari tingkah laku siswa pada saat proses pembelajaran.

Dari hasil wawancara yang telah dilakukan dengan guru Bahasa Inggris di sekolah ini diperoleh bahwa motivasi belajar siswa yang kurang disebabkan karena siswa menganggap mata pelajaran bahasa Inggris itu merupakan mata pelajaran yang sulit karena memiliki tata bahasa yang rumit. Permasalahan ini tentunya akan mempengaruhi hasil belajar siswa yang akan diperolehnya. Berbicara mengenai motivasi belajar, hal ini tentunya dipengaruhi oleh beberapa faktor diantaranya seperti faktor intrinsik dan ekstrinsik. Motivasi belajar siswa akan meningkat jika mendapatkan kegiatan yang menarik dalam belajar. Begitupun sebaliknya, motivasi belajar siswa akan menurun jika ia tidak mendapatkan kegiatan yang menarik dalam proses pembelajaran. Maka dari itu, sangat penting untuk membuat proses pembelajaran semenarik mungkin sehingga siswa akan tertarik untuk mengikuti proses pembelajaran.

Untuk meningkatkan motivasi belajar siswa dalam belajar bahasa inggris, maka dipandang untuk mencari metode ataupun media pembelajaran yang tepat dan inovatif untuk digunakan dalam proses pembelajaran. Dari berbagai hasil penelitian sebelumnya, diperoleh bahwa salah satu media pembelajaran yang efektif dalam meningkatkan motivasi belajar siswa ialah dengan menggunakan media youtube. Salah satunya yakni penelitian yang dilakukan oleh (Dimyati dan Mujiono, 2006) yang menggambarkan bahwa melalui video sebagai media pembelajaran membuat kegiatan pembelajaran pada siswa lebih terarah. Selain itu media video youtube dalam hal ini dipandang dapat menghadirkan sesuatu yang dapat dilihat dan didengar sehingga dapat memotivasi siswa untuk belajar dan memberikan pengalaman belajar kepada siswa sehingga nantinya akan berpengaruh pada motivasi siswa tersebut. Berdasarkan latar belakang yang telah dipaparkan di atas, maka perlu diadakan penelitian tentang peningkatan motivasi belajar bahasa Inggris siswa di sekolah tersebut dengan menggunakan media youtube berbasis various approaches. Various approaches yang dimaksud dalam hal ini yakni guru dapat menggunakan berbagai model pembelajaran dalam menggunakan media pembelajaran youtube.

\section{METODE PENELITIAN}

Jenis penelitian yang digunakan ialah penelitian tindakan kelas (Classroom Action Research), dalam penelitian ini peneliti bekerja sama dengan guru Bahasa Inggris di sekolah ini. Peneliti dalam hal ini berperan sebagai pengamat yang akan mengamati jalannya penelitian. Adapun teknik pengumpulan data yang digunakan dalam penelitian ini terdiri atas observasi dan angket. Berikut adalah penjelasan masingmasing teknik pengumpulan data:

1. Observasi: Observasi yang dimaksud dalam hal ini yakni pengamatan yang dilakukan oleh peneliti terhadap gejalagejala yang diteliti. Melalui teknik ini nantinya peneliti dapat mengetahui bagaimana pelaksanaan pengajaran di dalam kelas.

2. Angket: Untuk mengetahui motivasi belajar siswa, maka peneliti menggunakan 
angket. Angket dalam penelitian ini berisi kumpulan pernyataan atau pertanyaan yang tersusun secara sistematis dalam sebuah daftar pertanyaan. Sebelum dilakukan pengambilan data terkait dengan motivasi belajar siswa angket yang akan digunakan terlebih dahulu diuji validitas dan reliabilitasnya. Hal ini dilakukan untuk dapat sampai kepada kesimpulan mengenai layak tidaknya setiap item pada angket dalam mengukur motivasi belajar bahasa Inggris siswa

Penelitian ini akan dilaksanakan dalam dua siklus, yang setiap siklusnya dilaksanakan dua kali pertemuan khususnya dalam proses pembelajaran. Apabila siklus pertama belum mendapatkan hasil yang dicapai maka peneliti melanjutkan ke siklus selanjutnya. Prosedur dalam peelitian ini meliputi tahap persiapan, pelaksanaan pembelajaran, pengamatan dan tahap refleksi. Teknik analisis data yang digunakan dalam penelitian ini yaitu statistik deskriptif dengan menggunakan pengkategorisasian motivasi belajar dari Azwar (2004). Berikut adalah pengkategorisasian motivasi belajar siswa:

\section{Tabel 1. Kategorisasi Motivasi Belajar}

\begin{tabular}{cc}
\hline $\begin{array}{c}\text { Taraf Motivasi } \\
\text { Belajar }\end{array}$ & Kategorisasi \\
\hline $\mathrm{X} \leq \mathrm{M}-1,5 \sigma$ & Sangat Rendah \\
$\mathrm{M}-1,5 \sigma<\mathrm{X} \leq \mathrm{M}-$ & Rendah \\
$0,5 \sigma$ & \\
$\mathrm{M}-0,5 \sigma<\mathrm{X} \leq \mathrm{M}+$ & Sedang \\
$0,5 \sigma$ & \\
$\mathrm{M}+0,5 \sigma<\mathrm{X} \leq \mathrm{M}$ & Tinggi \\
$+1,5 \sigma$ & \\
$\mathrm{X}>\mathrm{M}+1,5 \sigma$ & Sangat Tinggi \\
\hline
\end{tabular}

Keterangan :

M: Skor Rata-Rata Hipotetik

$\sigma:$ Standar Deviasi Hipotetik

\section{HASIL DAN PEMBAHASAN}

Sebelum menggunakan angket yang nantinya bertujuan untuk mengukur motivasi belajar siswa, terlebih dahulu peneliti melakukan uji validitas dan uji reliabilitas terhadap angkat tersebut. Tipe validitas yang digunakan untuk menguji tingkat validitas instrument motivasi belajar adalah uji Korelasi Pearson Product Moment. Standar yang digunakan dalam penelitian ini agar dikatakan valid adalah setiap item pernyataan sebaiknya memiliki korelasi (r) dengan skor total masing-masing variabel $\geq 0,25$. Dari hasil pengujian diperoleh bahwa keseluruh item dalam angket memiliki nilai korelasi (r) $\geq 0,25$. Oleh karena itu dapat disimpulkan bahwa keseluruhan item pertanyaan sudah valid. Selain uji validitas, peneliti juga melakukan uji reliabilitas terhadap instrument motivasi belajar yang akan digunakan. Selain uji validitas, peneliti juga melakukan uji Reliabilitas. Tipe Reliabilitas yang dilakukan yakni uji Alpha Cronbach dengan menggunakan SPSS-18. Standar yang digunakan yaitu jika nilai alpha alpha $>0,80$ ini mensugestikan seluruh item reliabel dan seluruh tes secara konsisten secara internal karena memiliki reliabilitas yang kuat. Hasil analisis data menunjukkan bahwa nilai Cronbach's Alpha sebesar 0,85. Hal tersebut menandakan bahwa seluruh item pertanyaan memiliki reliabilitas yang kuat.

Sebelum pelaksanaan siklus pertama, peneliti terlebih dahulu mengukur motivasi belajar awal siswa dan memberikan tes untuk mengetahui hasil belajar sementara siswa yang menjadi subjek dalam penelitian ini. Berikut adalah hasil dari pengukuran motivasi belajar siswa dengan menggunakan instrumen yang sebelumnya telah dilakukan uji validitas dan uji reliabilitas. Dengan menggunakan kategorisasi motivasi belajar yang telah dijelaskan pada bagian sebelumnya, kita dapat melihat interval masing- masing kategorisasi motivasi belajar siswa. Langkah awal yang dilakukan sebelum mengkategorisasikan motivasi belajar siswa 
yakni menentukan mean hipotetik dan standar deviasi hipotetik. Dari hasil penghitungan diperoleh bahwa mean hipotetik yakni 37,5 sedangkan standar deviasi hipotetik adalah
7,5. Dari nilai mean hipotetik dan standar deviasi hipotetik tersebut kita dapat membuat kategorisasi motivasi belajar seperti dibawah ini:

Tabel 2. Kategorisasi Motivasi Belajar

\begin{tabular}{cc}
\hline Taraf Motivasi Belajar & Kategorisasi \\
\hline $\mathrm{X} \leq 26,25$ & Sangat Rendah \\
$26,25<\mathrm{X} \leq 33,75$ & Rendah \\
$33,75<\mathrm{X} \leq 41,25$ & Sedang \\
$41,25<\mathrm{X} \leq 48,75$ & Tinggi \\
$\mathrm{X}>48,75$ & Sangat Tinggi \\
\hline
\end{tabular}

Sebelum pelaksanaan proses pembelajaran, peneliti mengukur motivasi belajar siswa dalam hal ini bisa disebut dengan pre test. Berikut adalah data mengenai motivasi belajar siswa sebelum proses pembelajaran:

Tabel 3. Motivasi Belajar Pada Tes Awal

\begin{tabular}{ccc}
\hline Mean & $\begin{array}{c}\text { Standar } \\
\text { Deviasi }\end{array}$ & Kategori \\
\hline 33,74 & 0,91 & Rendah
\end{tabular}

Dari data tersebut, kita dapat melihat bahwa rata- rata motivasi belajar siswa pada saat tes awal yakni 33,74 dengan standar deviasi 0,91. Berdasarkan tabel kategorisasi motivasi belajar maka dapat disimpulkan bahwa pada bagian ini rata- rata motivasi belajar siswa berada pada kategori rendah. Setelah mengetahui gambaran awal motivasi belajar siswa, maka dilakukanlah proses pembelajaran. Siklus pertama dilaksanakan selama 2 kali pertemuan dalam artian proses pembelajaran. Setelah melakukan pembelajaran pada siklus pertama dengan menggunakan model pembelajaran tipe TSTS dengan menggunakan media Youtube, peneliti kembali mengukur motivasi belajar yang dimiliki. Berikut adalah data mengenai motivasi belajar siswa setelah siklus pertama:

\begin{tabular}{ccc}
\multicolumn{3}{c}{ Tabel 4. } \\
\hline Mean & $\begin{array}{c}\text { Standar } \\
\text { Deviasi }\end{array}$ & Kategori \\
\hline 41,25 & 4,91 & Tinggi
\end{tabular}

Dari data tersebut, kita dapat melihat bahwa rata- rata motivasi belajar siswa setelah melalui siklus pertama yakni 41,25 dengan standar deviasi 4,91. Berdasarkan tabel kategorisasi motivasi belajar maka dapat disimpulkan bahwa pada bagian ini rata- rata motivasi belajar siswa berada pada kategori tinggi. Setelah itu, selanjutnya peneliti melanjutkan siklus kedua. Siklus kedua juga dilaksanakan selama 2 kali pertemuan. Model pembelajaran yang digunakan adalah adalah demonstrasi. Setelah melakukan pembelajaran pada siklus kedua, peneliti kembali mengukur motivasi belajar yang dimiliki oleh siswa. Berikut adalah data mengenai motivasi belajar siswa setelah siklus kedua: 
Tabel 5. Motivasi Belajar Pada Siklus 2

\begin{tabular}{ccc}
\hline Mean & $\begin{array}{c}\text { Standar } \\
\text { Deviasi }\end{array}$ & Kategori \\
\hline 48,28 & 3,13 & Tinggi
\end{tabular}

Dari data tersebut, kita dapat melihat bahwa rata- rata motivasi belajar siswa setelah melaui siklus kedua yakni 48,28 dengan standar deviasi 3,13. Berdasarkan tabel kategorisasi motivasi belajar maka dapat disimpulkan bahwa pada bagian ini rata- rata motivasi belajar siswa berada pada kategori tinggi. Dari uraian di atas menunjukkan adanya peningkatan motivasi belajar Bahasa Inggris siswa mulai dari pada saat pre test, siklus pertama dan siklus kedua. Pada saat pre test rata- rata motivasi belajar siswa hanya 33, 74 sedangkan setelah siklus kedua, rata- rata motivasi belajar siswa adalah 48,28. Dari data tersebut dapat dilihat bahwa terdapat peningkatan motivasi belajar siswa sebanyak 14,54

\section{KESIMPULAN}

Berdasarkan hasil penelitian yang diperoleh hasil penelitian pada saat pre test, siklus I dan siklus II maka dapat disimpulkan bahwa penggunaan penggunaan media youtube berbasis various approaches dapat meningkatkan motivasi belajar siswa. Motivasi belajar Bahasa Inggris yang diperoleh dari kuesioner pada tes awal berada pada kategori rendah dengan skor rata-rata (M) sebesar 33,74. Sedangkan pada siklus pertama motivasi belajar siswa berada pada kategori tinggi dengan skor rata-rata (M) sebesar 41,25 dan pada siklus kedua motivasi belajar siswa berada pada kategori tinggi dengan skor rata-rata (M) sebesar 48,28.

\section{DAFTAR PUSTAKA}

Azwar, S. (2004). Penyusunan Skala Psikologis. Yogyakarta: Pustaka Pelajar.
Dimyati dan Mujiono. (2006). Belajar dan Pembelajaran. Jakarta: Rineka Cipta.

Yusri, Y., Mantasiah, R., \& Jufri, J. (2018). The Use Of Two Stay Two Stray Model in English Teaching to Increase Student's Learning Outcome. Journal of Advanced English Studies, 1(1), 39-43.

Mantasiah, R. (2018, June). Pay It Forward Model in Foreign Language Learning to Increase Student's Self Efficacy and Academic Motivation. In Journal of Physics: Conference Series (Vol. 1028, No. 1, p. 012178). IOP Publishing.

Romadloni, A., \& Mantasiah, R. Intercultural approach in foreign language learning to improve students' motivation. Senior Editors, 61

Qalbi, U. N., Mantasiah, R., Jufri, J., \& Yusri, Y. (2017). Efektivitas Model Pembelajaran Kooperatif Tipe Teams Games Tournaments dalam Keterampilan Menulis Bahasa Jerman Siswa Kelas XII IPA SMA Negeri 1 Bontonompo Kabupaten Gowa. Indonesian Journal of Educational Studies, 20(1).

Qudus, M., \& Yusri, Y. (2017). Keefektifan Penggunaan Metode Audio Lingual dalam Pembelajaran Kemampuan Menyimak Bahasa Jerman. Indonesian Journal of Educational Studies, 20(2).

Zheng, B., Yim, S., \& Warschauer, M. (2018). Social media in the writing classroom and beyond. The TESOL Encyclopedia of English Language Teaching, 1-5.

Aniroh, K., Hanum, L., \& Ariyanto, A. A. G. (2018). The Effectiveness of YouTube Live Streaming as Digital 
Learning Media in Tourism and Guiding Subject.

Volkova, S., Ranshous, S., \& Phillips, L. (2018). Predicting Foreign Language Usage from English-Only Social Media Posts. In Proceedings of the 2018 Conference of the North American Chapter of the Association for Computational Linguistics: Human Language Technologies, Volume 2 (Short Papers) (Vol. 2, pp. 608-614). 